\title{
MINAT PESERTA DIDIK DALAM BEROLAHRAGA PADA MASA PANDEMI COVID-19
}

\author{
Rakha Candra Pangestu $^{1 *}$, I Wayan Artanayasa ${ }^{2}$, I Made Satyawan ${ }^{3}$ \\ ${ }^{123}$ Prodi Pendidikan Jasmani Kesehatan dan Rekreasi, Jurusan Pendidikan Olahraga Fakultas Olahraga dan Kesehatan \\ Universitas Pendidikan Ganesha, Indonesia \\ *Corresponding author: rakhacp03@gmail.com
}

\begin{abstract}
Abstrak
Rendahnya minat siswa dalam berolahraga di masa pandemi sekarang ini berpengaruh terhadap kesehatan siswa. Sehingga diperlukan kiat guna meningkatkan minat siswa dalam berolahraga. Penelitian ini bertujuan untuk mengetahui minat peserta didik kelas XI SMA Negeri 1 Pekutatan dalam berolahraga di masa pandemi covid-19. Penelitian ini adalah deskriptif kuantitatif dengan jenis penelitian survei. Populasi dalam penelitian ini adalah seluruh peserta didik kelas XI SMA Negeri 1 Pekutatan dengan jumlah keseluruhan 255 peserta didik. Teknik pengambilan sampel penelitian menggunakan non random sampling yaitu quota sampling dengan besaran $25 \%$ dari total populasi sehingga jumlah sampel dalam penelitian ini berjumlah 63 orang. Data dianalisis menggunakan statistik deskriptif kuantitatif dengan kategori interval. Hasil penelitian menunjukkan bahwa pada faktor ekstrinsik minat peserta didik kelas XI SMA Negeri 1 Pekutatan dalam berolahraga pada masa pandemi covid-19 mendapatkan nilai $74 \%$ dalam interval kategori dinyatakan tinggi. Pada faktor intrinsik minat peserta didik kelas XI SMA Negeri 1 Pekutatan dalam berolahraga pada masa pandemi covid-19 mendapat nilai 80\% dalam interval kategori dinyatakan tinggi. Dari kedua indikator pada variabel, minat peserta didik kelas XI SMA Negeri 1 Pekutatan memperoleh skor $77 \%$. Pada interval kategori tergolong kategori sangat tinggi. Saran yang dapat disampaikan adalah peserta didik tetap melakukan kegiatan olahraga di masa pandemi covid-19 agar daya tahan tubuh semakin kuat. Kesimpulan dari penelitian ini adalah minat berolahraga peserta didik kelas XI SMA Negeri 1 Pekutatan pada masa pandemi covid-19 sangat tinggi. Peneliti menyarankan agar peserta didik tetap berolahraga walaupun masa pandemi covid-19 telah selesai.
\end{abstract}

Kata Kunci :Minat, Berolahraga, Pandemi covid-19

\section{Abstract}

The low interest of students in exercising during the current pandemic affects students' health. So we need tips to increase student interest in sports. This study aims to determine the interest of eleventh graders of SMA Negeri 1 Pekutatan in exercising during the covid-19 pandemic. This research is descriptive quantitative with the type of survey research. The population in this study were all eleventh-grade students of SMA Negeri 1 Pekutatan, with 255 students. The sampling technique used was non-random sampling, namely quota sampling with $25 \%$ of the total population, so that the number of samples in this study amounted to 63 people. Data were analyzed using quantitative descriptive statistics with interval categories. The results showed that on the irrelevant factor, the interest of eleventh graders at SMA Negeri 1 Pekutatan in exercising during the COVID-19 pandemic got a score of 74\% in the declared high category interval. In the intrinsic factor, the interest of eleventh graders at SMA Negeri 1 Pekutatan in exercising during the COVID-19 pandemic scored $80 \%$ in the category interval, which was high. From the two indicators on the variables, the interest of the eleventh graders of SMA Negeri 1 Pekutatan obtained $77 \%$. The category interval is classified as a very high category. The advice that can be conveyed is that students continue to carry out sports activities during the COVID-19 pandemic so that their immune system becomes stronger. This study concludes that the interest in sports for eleventh graders of SMA Negeri 1 Pekutatan during the COVID-19 pandemic is very high. Researchers suggest that students continue to exercise even though the COVID-19 pandemic has ended.

Keywords: Interest, Sports, Covid-19 Pandemic

$\begin{array}{ll}\text { History: } & \text { Publisher: Undiksha Press } \\ \text { Received: 24 April } 2021 & \text { Licensed: This work is licensed under } \\ \text { Revised: 1 Mei } 2021 & \text { accepted: 26 Mei } 2021\end{array}$




\section{Pendahuluan}

Olahraga adalah suatu bentuk aktivitas fisik yang terencana dan tersrukturyang melibatkan gerakan tubuh berulah-ulang dan ditunjukan untuk meningkatkan kebugaran jasmani. Olahraga merupakan sebagian kebutuhan pokok dalam kehidupan sehari-hari karena dapat meningkatkan daya tahan tubuh seseorang. Olahraga dapat dimulai sejak usia dini hingga usia lanjut dan dapat dilakukan setiap hari. Menurut Janpurba (2011), jika seseorang melakukan olahraga secara rutin maka akan dapat meningkatkan massa ototnya, karena latihan tersebut dapat merangsang sel otot untuk tumbuh menjadi lebih besar dan sel-sel otot yang semula istirahat akan menjadi aktif lagi.

Masyarakat Indonesia saat ini masih kurang menyadari akan pentingnya hidup sehat. Hal ini terjadi karena kurangnya animo/minat dan apresiasi masyarakat terhadap olahraga. Tapi melihat beberapa bulan ke belakang masyarakat Indonesia termasuk diwilayah-wilayah terpencil animo/minat masyarakat dalam berolahraga sangatlah tinggi di karenakan saat ini Negara Indonesia sedang dilanda pandemi virus covid-19 yang membuat semua masyarakat tidak bisa beraktivitas seperti normal dikarena pemerintah mengeluarkan peringatan untuk bekerja dirumah, beribadah dirumah, belajar dirumah dan pemerintah juga menganjurkan untuk menjaga kesehatan diri sendiri melalui berolahraga dirumah yang dimana berolaharaga pada masa pandemi covid-19 dapat membuat imonitas tubuh lebih kuat untuk melawan penyakit yang datang. Dalam menjaga kesehatan diri untuk menjaga imonitas tubuh supaya tetap terjaga dimasa pandemi covid-19 banyak aktifitas olahraga yang bisa di lakukan dirumah ataupun diluar rumah dalam menjaga imonitas tubuh

Penyakit yang ditimbulkan oleh Novel Corona Virus 2019 ( Covid-19) adalah penyakit yang menular yang disebabkan oleh SARS-COV-2, salah satu jenis koronavirus dimana penyakit ini telah menjadi pademi ditahun 2019-2020. Infeksi menyebar dari satu orang ke orang lain melalui percikan (droplet) dari saluran pernapasan yang sering dihasilkan saat batuk atau bersin. Sejak merebaknya pandemi yang disebabkan oleh virus corona di Indonesia, banyak cara yang dilakukan oleh pemerintah untuk mencegah penyebarannya. Dengan persebaran pandemi covid-19 yang begitu cepat melanda dunia hal ini menyebabkan dosen dan mahasiswa mau tidak mau berjuang dengan keadaan ini. Situasi yang sebelumnya proses pembelajaran berlangsung dengan tatap muka, dengan bimbingan langsung bertemu fisik dengan proses dikelas menjadi suatu hal yang tidak bisa dilaksanakan lagi.

Pandemi covid-19 menyebabkan sekolah di seluruh indonesia pun terkena dampaknya. Sekolah sudah diliburkan oleh pemerintah sejak beberapa bulan lalu. Pembelajaran pun dilakukan menggunakan online keseluruh peserta didik tidak terkecuali juga mahasiswa di perguruan tinggi suwasta maupun Negeri . Dalam menjaga kesehatan diri untuk meningkatkan imunitas tubuh dan memperkuat imunitas tubuh setiap peserta didik haruslah rajin dalam melakukan olahraga dirumah atau diluar rumah karena banyak manfaat dalam berolahraga dimana dalam melakukan aktifitas fisik juga dikenal untuk mengurangi depresi, stres dan kecemasan, dan meningkatkan kepercayaan diri, tingkat energi, kualitas tidur dan kemampuan untuk berkonsentrasi. VicHealt, 2010:1 (dalam Yudik Prasetyo, 2013:219-228).

Di masa pandemi seperti sekarang ini pserta didik dihimbau agar melakukan olahraga setiap harinya agar imunitas tubuh bertambah kuat. Tetapi tetap harus mengikuti aturan dari pemerintah berjaga jarak dengan satu sama lain dan melakukan olahraga di halaman rumah saja agar menghindari dari paparan virus covid-19 ini. Dari observasi awal peneliti mendapatkan data jumlah peserta didik di bagi menjadi Kelas X berjumlah 224 orang, kelas XI berjumlah 255 orang, sedangkan kelas XII berjumlah 268 orang.

Berikut ini beberapa penelitian yang relevan yang pernah dilakukan secara umum penelitian-penelitian tersebut menunjukan bahwa aktivitas jasmani yang di lakukan peserta didik saat pandemi covid-19 : 1) (Susanto, 2020) menyimpulkan latihan yang cocok untuk 
menghindari kontak dengan orang banyak dan menjaga meningkatkan kebugaran. Bentukbentuk latihan semacam ini termasuk pada latihan penguatan untuk keseimbangan dan kontrol dan latihan. 2) (Putrantana, 2017) menyimpulkan disinilah peran penting permainan tradisional, saat anak melakukan permainan tradisional secara tidak sadar anak sudah belajar tentang karakter seperti karakter ramah, peduli, sabar, dan seterusnya. 3) (Kasim, 2011) menyimpulkan motovasi dan minat guru merupakan hal untuk meningkatkan manajemen kinerja guru.

Berdasarkan latar belakang diatas maka diajukan judul penelitian "Minat Peserta Didik Dalam Berolahraga Pada Masa Pandemi Covid-19 Di Kelas XI SMA Negeri 1 Pekutatan"

\section{Metode}

Penelitian ini merupakan penelitian deskriptif kuantitatif dengan jenis penelitian survey. Dalam penelitian ini peneliti tidak memberikan perlakuan, tetapi langsung mengambil data dari sumber data. Penelitian ini dirancang untuk mendeskripsikan dan menjelaskan tentang kondisi minat peserta didik dalam berolahraga di masa pandemi covid19. Penelitian dirancang melalui dari tahap :

a. Perencanaan yang berdiri dari tahap analisis kebutuhan dan adaptasi instrument.

b. Pelaksanaan yang terdiri atas tahap pengumpulan data, analisis data dan pembahasan.

c. pelaporan.

Pada tahapan persiapan akan dilakukan penyusunan instrumen penelitian. Instrumen penelitian ini meliputi test. Kemudian pada tahap pelaksaan penelitian dilakukan pengambilan data menggunakan instrumen yang sudah disiapkan pada tahap perencanaan. Test diberikan pada kelas sampel yang di tentukan secara random sampling. Kemudian kegiatan pada tahap pelaporan meliputi analisis data secara keseluruhan dan perumusan simpulan, serta pembuatan laporan hasil penelitian.

Variabel Penelitian

Variabel dalam penelitian ini adalah variabel bebas ialah minat peserta didik SMA Negeri 1 Pekutatan serta variabel terikatnya adalah menjaga kebugaran jasmani pada masa pandemi covid-19. Kemudin akan diukur dengan angket sebagai instrumen yang diberikan kepada peserta didik di SMA Negeri 1 Pekutatan.

Populasi Penelitian

Populasi adalah keseluruhan atau himpunan objek dengan ciri yang sama (Kanca, 2010). Populasi dapat berupa himpunan orang, benda, kejadian, kasus, waktu atau tempat dengan sifat dan ciri sama. Populasi dalam penelitian ini adalah seluruh peserta didik kelas XI SMA Negeri 1 Pekutatan dengan rincian sebagai berikut:

Tabel 1. Populasi penelitian peserta didik SMA Negeri 1 Pekutatan

\begin{tabular}{lll}
\hline NO & Kelas & Jumlah Peserta Didik \\
\hline 1 & XI MIA 1 & 32 Orang \\
2 & XI MIA 2 & 32 Orang \\
3 & XI MIA 3 & 34 Orang \\
4 & XI MIA 4 & 34 Orang \\
5 & XI IPS 1 & 31 Orang \\
6 & XI IPS 2 & 30 Orang \\
7 & XI IPS 3 & 32 Orang \\
\hline
\end{tabular}




\begin{tabular}{lll}
\hline 8 & XI Bahasa & 30 Orang \\
& Total & 255 Orang \\
\hline
\end{tabular}

Sampel Penelitian

Sampel adalah himpunan bagian ( sebagian ) populalasi yang diambil secara representative dari populasi (Kanca, 2010). Menurut Suharsini Arikunto dalam Rawes ( 2018:40 ), apabila subjek kurang dari 100, lebih baik diambil semua sehingga disebut penelitian populasi. Tetapi apabila subjek penelitian besar, dapat diambil antara 10\%-15\% atau 20\%-25\% atau lebih. Adapun dalam penelitian ini pengambilan sampel menggunakan non random sampling yang dilakukan dengan cara Quota Sampling yang artinya pengambilan sampel dengan menetapkan subyek yang akan diteliti

Berdasarkan pendapat diatas sampel dalam penelitian ini adalah $25 \%$ x $255=63$, responden adalah jumlah sampel dalam penelitian ini yaitu 63 orang peserta didik kelas XI SMA Negeri 1 Pekutatan.

Tabel 2 Sampel Penelitian Peserta Didik SMA Negeri 1 Pekutatan

\begin{tabular}{lllll}
\hline Sekolah & Kelas & Populasi & $\begin{array}{l}\text { Presentase } \\
\text { Pengambilan }\end{array}$ & $\begin{array}{l}\text { Sampel } \\
\text { (orang) }\end{array}$ \\
SMA Negeri 1 Pekutatan & XI & 255 orang & $25 \%$ & 63 Orang \\
\hline
\end{tabular}

Metode Pengumpulan Data

Kuisioner merupakan teknik oengumpulan data yang dilakukan dengan cara memberi seperangkat pertanyaan atau pernyataan tertulis kepada responden untuk dijawabnya. Kuisioner merupakan teknik pengumpulan data yang efisien bila peneliti tahu dengan pasti variabel yang akan diukur dan tahu apa yang diharapkan dari responden.

Pengumpulan data dilakukan dengan menggunakan instrumen penilaian berupa angket untuk mengidentifikasi minat peserta didik SMA Negeri 1 Pekutatan. Penilaian berupa angket ini berisi bagian isi dan bagian alasan. Bagian memuat respon peserta didik terhadap pilihan ganda angket yang disediakan yang berkaitan dengan konten, sedangkan bagian kedua menuntut peserta didik agar memberikan alasan atas jawaban pada bagian pertama.

Akan digunakannya angket penelitian terdiri dari butir-butir pertanyaan minat peserta didik yang termasuk kedalam kuisioner tertutup karena penelitian sudah menyediakan jawaban sehingga responden tinggal memilih. Ditinjau dari jawaban yang diberikan angket yang digunakan penelitian termasuk angket tertutup karena respon menjawab sesuai dengan pilihan yang sudah disediakan. Kuisioner diberikan kepada peserta didik kelas XI SMA Negeri 1 Pekutatan.

Instrumen Penelitian

Instrument penilaian adalah alat atau fasilitas yang digunakan oleh peneliti dalam mengumpulkan data agar pekerjaan lebih mudah dan hasilnya lebih baik, dalam arti lebih cermat, lengkap, dan sistematis sehingga lebih mudah diolah (Arikunto, 2006). Sedangkan Instrument penelitian adalah suatu alat yang digunakan untuk mengukur fenomena alam ataupun sosialyang diamati (Budiarta, 2018).

Dalam penelitian ini instrument yang digunakan adalah angket yang berisi pernyataan yang digunakan untuk mengungkap minat peserta didik untuk menjaga kebugaran jasmani ditinjau dari faktor instrinsik ( rasa tertarik, perhatian, aktivitas ) dan faktor ekstrinsik ( lingkungan dan alat atau fasilitas ).

Teknik Analisis Data 
Penelitian ini akan menggunakan teknik analisis data deskriptif dengan presentase dari jawaban peserta didik. Jawaban diberikan peserta didik akan bermacam-macam karena masing-masing individu memiliki perbedaan pendapat. Keseluruhan data berupa angket yang berhasil dikumpulkan kemudian dianalisis dengan menggunakan presentase. Analisis tersebut dilakukan untuk mengetahui minat peserat didik kelas XI SMA Negeri 1 Pekutatan dalam berolahraga di masa pandemi covid-19.

Instrumen yang digunakan berupa angket terdiri dari pernyataan positif dan negatif, tingkat kesetujuan responden diklasifikasi yaitu Sangat Setuju ( SS ), Setuju ( S ), Tidak Setuju ( TS ), dan Sangat Tidak Setuju ( STS ). Instrumen yang digunakan berupa angket akan diuji reliabilitas dan validasinya dengan melakukan uji ahli.

Agar data yang diperoleh dalam penelitian ini berupa data kuantitatif, maka setiap butir jawaban diberi skor dalam bentuk skala likert yang telah dimodifikasi dengan alternative jawaban.

\section{Hasil dan Pembahasan}

Dalam penelitian ini variabel bebas yang di ambil adalah Minat peserta didik serta variabel terikatnya adalah menajaga kebugaran jasmani. Hasil dari data penelitian ini diperoleh melalui kuisioner yang diisi oleh setiap responden. Untuk mempermudah penyajian data penelitian, maka data minat peserta didik sebelum dianalisis perlu dideskripsikan. Terdapat beberapa faktor yang diamati terhadap minat peserta didik dalam berolahraga pada masa pandemi covid-19 yaitu kebutuhan, pengalaman, perhatian, rasa tertarik, kenyamanan, sarana prasarana, aktivitas, kualitas sarana, kebugaran, dan terakhir aplikasi dengan 20 pernyataan atau pertanyaan.

PEMBAHASAN HASIL

Berdasarkan deskriptif frekuensi dapat didefinisikan tanggapan responden terhadap itemitem pernyataan variabel minat sebagai berikut :

1. Tanggapan responden terhadap pernyataan nomor 1 yaitu "Saya memerlukan berolahraga pada masa pandemi covid-19" sebanyak 32 orang menyatakan sangat setuju, 30 orang menyatakan setuju, 1 orang menyatakan tidak setuju. Dalam pernyataan ini meperoleh nilai $87,3 \%$. Bila dikonversikan pada skala penilaian katagori pernyataan no 1 berada dalam kategori sangat tinggi. Artinya peserta didik membutuhkan olahraga pada masa pandemi covid-19.

2. Tanggapan responden terhadap pernyataan nomor 2 yaitu "Saya harus memiliki kesehatan yang prima di masa pandemi covid-19" sebanyak 44 orang menyatakan sangat setuju dan 19 orang menyatakan setuju. Dalam pernyataan ini memperoleh nilai 92,4\%. Bila dikonversikan pada skala penilaian katagori pernyataan nomor 2 berada di kategori sangat tinggi. Artinya peserta didik harus memiliki kesehatan yang prima di masa pandemi covid-19 ini.

3. Tanggapan responden terhadap pernyataan nomor 3 yaitu "Berolahraga merupakan aktivitas yang membosankan" sebanyak 45 orang menyatakan tidak setuju dan 18 orang menyatakan sangat tidak setuju. Dalam pernyataan ini memperoleh nilai 82,1\%. Bila dikonversikan pada skala penilaian katagori pernyataan nomor 3 berada pada kategori sangat tinggi. Artinya berolahraga merupakan kegiatan yang tidak membosankan.

4. Tanggapan responden terhadap pernyataan nomor 4 yaitu "Berolahraga memberikan hal yang positif bagi diri saya" sebanyak 33 orang menyatakan sangat setuju, 29 orang menyatakan setuju dan 1 orang menyatakan tidak setuju. Dalam pernyataan ini memperoleh nilai $87,7 \%$. Bila dikonversikan pada skala penilaian katagori maka pernyataan nomor 4 berada pada kategori sangat tinggi. Artinya berolahraga memberikan hal yang positif bagi orang tersebut. 
5. Tanggapan responden terhadap pernyataan nomor 5 yaitu "Saya tertarik untuk mencari konten/vidio kebugaran jasmani youtube." Sebanyak 10 orang menyatakan sangat setuju, 50 orang menyatakan setuju dan 3 orang menyatakan tidak setuju. Dalam pernyataan ini memperoleh nilai $77,8 \%$. Bila dikonversikan pada skala penilaian katagori maka pernyataan nomor 5 masuk dalam kategori tinggi. Artinya peserta didik tertarik mencari konten atau vidio kebugaran jasmani di youtube.

6. Tanggapan responden terhadap pernyataan nomor 6 yaitu "Saya tertarik untuk melakukan aktivitas jasmani yang mudah." Sebanyak 22 orang menyatakan sangat setuju, 41 orang menyatakan setuju. Dalam pernyataan ini memperoleh nilai $83,7 \%$. Bila dikonversikan pada skala penilaian katagori makan pernyataan nomor 6 masuk kedalam katefori sangat tinggi. Artinya peserta didik tertarik melakukan aktivitas jasmani yang mudah.

7. Tanggapan responden terhadap pernyataan nomor 7 yaitu "Saya tertarik untuk berolahraga setiap hari" sebanyak 19 orang menyatakan sangat setuju, 39 orang menyatakan setuju dan 5 orang menyatakan tidak setuju. Dalam pernyataan ini memperoleh nilai 80,6\%. Bila dikonversikan pada skala penilaian katagori maka pernyataan nomor 7 masuk kedalam kategori tinggi. Artinya peserta didik tertarik berolahraga setiap hari.

8. Tanggapan responden terhadap pernyataan nomor 8 yaitu "Saya tertarik berolahraga menggunakan alat-alat yang ada dirumah" sebanyak 18 orang menyatakan sangat setuju, 40 orang menyatakan setuju dan 5 orang menyatakan tidak setuju. Dalam pernyataan ini memperoleh nilai $80,2 \%$. Bila di konversikan pada skala penilaian katagori maka peranyataan nomor 8 masuk kedalam kategori \ tinggi. Artinya peserta didik tertarik berolahraga mengginakan alat-alat yang ada di rumah.

9. Tanggapan responden terhadap pernyataan nomor 9 yaitu "Saya merasa semangat berolahraga di masa pandemi covid-19" sebanyak 13 orang menyatakan sangat setuju, 46 orang menyatakan setuju dan 4 orang menyatakan tidak setuju. Dalam pernyataan ini memperoleh nilai 78,6\%. Bila dikonversikan pada skala penilaian katagori makan pernyataan nomor 9 masuk kedalam kategori tinggi. Artinya peserta didik bersemangat berolahraga saat masa pandemi covid-19.

10. Tanggapan responden terhadap pernyataan nomor 10 yaitu "Saya tidak nyaman dengan olahraga yang intensitas berat". Seanyak 9 orang menyatakan sangat setuju, 39 orang menyatakan setuju, 14 orang menyatakan tidak setuju, dan 1 orang menyatakan sangat tidak setuju. Dalam pernyataan ini memperoleh nilai 52,8\%. Bila dikonversikan pada skala penilaian katagori maka pernyataan 10 masuk kedalam kategori rendah. Artinya peserta didik tidak merasa nyaman bila olahraga menggunakan intesitas yang berat.

11. Tanggapan responden terhadap pernyataan nomor 11 yaitu: "Saya melakukan olahraga dengan prasarana disekitar rumah" sebanyak 15 orang menyatakan sangat setuju, 43 orang menyatakan setuju dan 5 orang menyatakan tidak setuju. Dalam pernyataan ini memperoleh nilai 79\%. Bila dikonversikan pada skala penilaian katagori maka pernyataan nomor 11 masuk ke dalam kategori tinggi. Artinya peserta didik melakukan olahraga dengan prasarana dirumah.

12. Tanggapan responden terhadap pernyataan nomor 12 yaitu : "Sarana yang ada sangat membantu saya dalam melakukan olahraga di masa pandemi covid-19" sebanyak 13 orang menyatakan sangat setuju, 44 orang menyatakan setuju dan 13 orang menyatakan tidak setuju. Dalam pernyataan ini memperoleh nilai 77,8\%. Bila dikonversikan pada skala penilaian katagori makan pernyataan nomor 12 masuk kedalam kategori tinggi. Artinya sara yang ada sangat membantu untuk melakukan olahraga dimasa pandemi covid-19. 
13. Tanggapan responden terhadap pernyataan nomor 13 yaitu : "Saya sangat suka dengan aktivitas olahraga dengan intensitas yang berat" sebanyak 2 orang menyatakan sangat setuju, 14 orang menyatakan setuju, 44 orang menyatakan tidak setuju dan 3 orang menyatakan sangat tidak setuju. Dalam pernyataan ini memperoleh nilai $56 \%$. Bila dikonversikan pada skala penilaian katagori maka pernyataan nomor 13 masuk kedalam kategori sedang. Artinya peserat didik kurang menyukai olahraga dengan intensitas tinggi.

14. Tanggapan responden terhadap pernyataan nomor 14 yaitu : "Saya tidak ada kendala dalam melakukan olahraga di rumah" sebanyak 8 orang menyatakan sangat setuju, 44 orang menyatakan setuju, 10 orang menyatakan tidak setuju dan 1 orang menyatakan sangat tidak setuju. Dalam pernyataan ini memperoleh nilai 51,6\%. Bila dikonversikan pada skala penilaian katagori maka pernyataan nomor 14 masuk kedalam kategori rendah. Artinya peserta didik masih terkendala melakukan olahraga dirumah.

15. Tanggapan responden terhadap pernyataan nomor 15 yaitu : "Mudahnya mencari alat olahraga dirumah" sebanyak 8 orang menyatakan sangat setuju, 37 orang menyatakan setuju, 18 orang menyatakan tidak setuju. Dalam pernyataan ini memperoleh nilai $71 \%$. Bila dikonversikan pada skala penilaian katagori maka pernyataan nomor 15 masuk kedalam kategori tinggi. Artinya peserta didik mudah mencari alat olahraga dirumah.

16. Tanggapan responden terhadap pernyataan nomor 16 yaitu : "Banyak alat-alat dirumah yang bisa digunakan untuk berolahraga" sebanyak 10 orang menyatakan sangat setuju, 38 orang menyatakan setuju, 14 orang menyatakan tidak setuju dan 1 orang menyatakan sangat tidak setuju. Dalam pernyataan ini memperoleh nilai $72,6 \%$. Bila dikonversikan pada skala penilaian katagori maka pernyataan nomor 16 masuk kedalam kategori tinggi. Artinya banyak alat-alat dirumah bisa digunakan untuk olahraga.

17. Tanggapan responden terhadap pernyataan nomor 17 yaitu : "Setelah melakukan olahraga saya merasa badan saya semakin bugar" sebanyak 25 orang menyatakan sangat setuju, dan 38 orang menyatakan setuju,. Dalam pernyataan ini memperoleh nilai 84,9\%. Bila dikonversikan pada skala penilaian katagori maka pernyataan nomor 17 masuk kedalam kategori sangat tinggi. Artinya setelah berolahraga peserat didik merasa badannya semakin bugar.

18. Tanggapan responden terhadap pernyataan nomor 18 yaitu : "Saya membuat pola hidup sehat dengan berolahraga secara rutin." sebanyak 21 orang menyatakan sangat setuju, 39 orang menyatakan setuju, 3 orang menyatakan tidak setuju. Dalam pernyataan ini memperoleh nilai $82,1 \%$. Bila dikonversikan pada skala penilaian katagori maka pernyataan nomor 18 masuk kedalam kategori sangat tinggi. Artinya peserta didik membuat pola hidup sehat dengan cara berolahraga.

19. Tanggapan responden terhadap pernyataan nomor 19 yaitu : "Banyak contoh vidio di youtube yang memudahkan saya untuk melakukan olahraga" sebanyak 21 orang menyatakan sangat setuju, 39 orang menyatakan setuju, 2 orang menyatakan tidak setuju dan 1 orang menyatakan sangat tidak setuju. Dalam pernyataan ini memperoleh nilai 81,7\%. Bila dikonversikan pada skala penilaian katagori maka pernyataan nomor 19 masuk kedalam kategori tinggi. Artinya banyak contoh vidio di youtube untuk memudahkan peserta didik melakukan olahraga.

20. Tanggapan responden terhadap pernyataan nomor 20 yaitu : "Saya tidak tahu contoh vidio olahraga di youtube" sebanyak 1 orang menyatakan sangat setuju, 6 orang menyatakan setuju, 39 orang menyatakan tidak setuju dan 17 orang menyatakan sangat tidak setuju. Dalam pernyataan ini memperoleh nilai 78,6\%. Bila dikonversikan pada skala penilaian katagori maka pernyataan nomor 20 masuk kedalam kategori tinggi. Artinya peserta didik tidak tahu contoh vidio olahraga di youtube. 


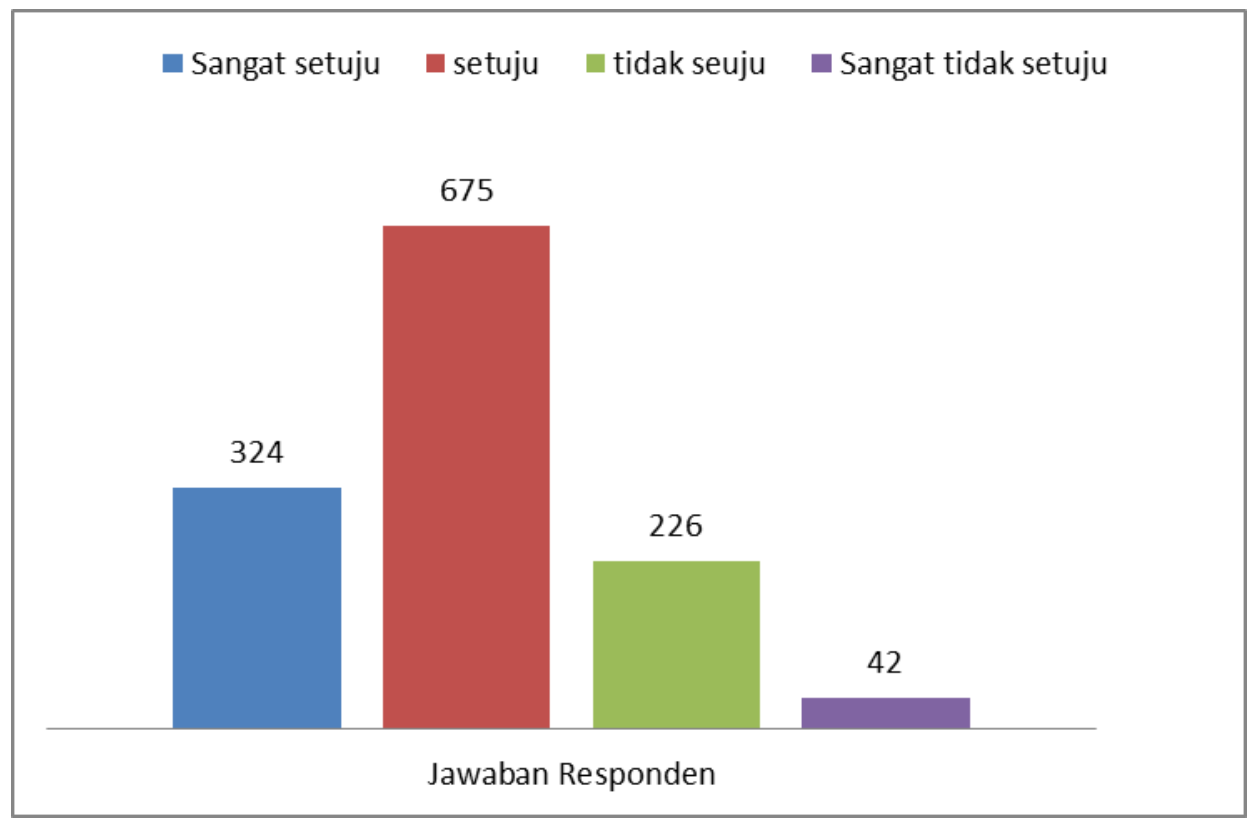

Gambar 1. Diagram Analisis Pernyataan

Dari gambar diagram di atas, dapat disimpulkan sebanyak 324 orang menjawab sangat setuju, 657 menjawab setuju, 226 menjawab tidak setuju dan 42 orang menjawab sangat tidak setuju.

Dilihat dari analisis responden 10 pernyataan minat instrinsik diatas, bila dirata-ratakan memperoleh nilai $80 \%$ dan 10 pernyataan minat ekstrinsik bila dirata-ratakan memperoleh nilai $74 \%$. Bila dikonversikan pada tabel interval kategori berada pada kategori sangat tinggi.

Bersadarkan pencapaian skor rata-rata pada setiap komponen indikator minat, diketahui bahwa 63 peserta didik sebagai sampel penelitian, dan masing-masing indikator minat sebanyak 20 pernyataan maka perhitungan jumlah skor rata-rata minat peserta didik kelas XI SMA Negeri 1 Pekutatan sebagai berikut :

Rumus :

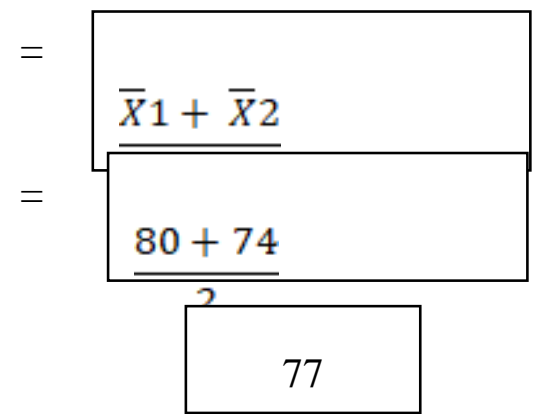

Berdasarkan hasil analisis data kedua indikator pada variabel minat peserta didik kelas XI SMA Negeri 1 Pekutatan memperoleh nilai 77\%. Pada interval katagori dikatakan tinggi.

\section{Simpulan}

Berdasarkan hasil analisis data enggunakan deskriptif kuantitatif dapat disimpulkan bahwa minat peserta didik kelas XI SMA Negeri 1 Pekutatan dalam berolahraga di masa pandemi covid-19 adalah baik. 
Saran

Berdasarkan kesimpula di atas, adapun saran yang dapat diberikan adalah sebgai berikut : 1) Bagi peserta didik, diharapkan agar meningkatkan minat dalam berolahraga pada masa pandemi covid-19 sehingga dapat menjaga kesehatan diri dan mencegah penularan covid-19 dengan meningkatkan imun tubuh melalui olahraga, 2) Bagi peneliti, bagi peneliti lain yang berminat mengadakan penelitian deskriptif kuantitatif tentang survei minat dalam berolahraga di masa pandemi covid-19 menjadikan hasil penelitian ini sebagai salah satu refrensi untuk meneliti dalam lingkup yang lebih luas, 3) Bagi Guru, diharapkan agar memberikan motivasi melalui media virtual untuk melakukan olahraga dimasa pandemi covid-19 sehingga peserta didik termotivasi dan dapat menjaga kesehatan diri dan mencegah penularan covid-19.

\section{Daftar Pustaka}

Arikunto, S. (2006). Prosedur Penelitian Suatu Pendekatan Praktik. Jakarta: PT Rineka Cipta.

Budiarta, R. (2018). Minat dan Motivasi Peserta Didik Terhadap Ekstrakurikuler woodball di Sekolah Menengah Atas Negeri 2 Banjar Kabupaten Buleleng Tahun Pelajaran 2017/2018. Fakultas Olahraga dan Kesehatan. Universitas Pendidikan Ganesha.

Kanca, I. N. (2010). Metode Penelitian Pengajaran Pendidikan Jasmani dan Olahraga. Singaraja: urusan Pendidikan Jasmani, Kesehatan, dan Rekreasi. Fakultas Olahraga dan Kesehatan Universitas Pendidikan Ganesha Singaraja.Undiksha.

Kasim, M. (2011). Pentingnya Motivasi dan Minat Terhadap Manajemen Kinerja Guru dalam Pelaksanaan Pembelajaran Pendidikan Jasmani, Olahraga dan Kesehatan. Retrieved from http://jurnal.untad.ac.id/jurnal/index.php/academica/article/download/2285/1478

Putrantana, A. B. (2017). Pembentukan Karakter Siswa Sekolah Dasar Melalui Permainan Tradisional pada Pendidikan Jasmani, Olahraga dan Kesehatan. Retrieved from http://pasca.im.ac.id/conferences/index.php/por/article/view/622

Susanto, N. (2020). Pengaruh Virus Covid 19 Terhadap Bidang Olahraga Di Indonesia. Retrieved from http://stamina.ppj.unp.ac.id/index.php/JST/article/view/491 